\title{
Causes of Fatal Accidents Involving Cranes in the Australian Construction Industry
}

\author{
Ehsan Gharaie, Helen Lingard and Tracy Cooke \\ School of Property, Construction and Project Management, RMIT University, Australia
}

\begin{abstract}
In ten years from 2004 to 2013, 359 workers died in the Australian construction industry because of work related causes. This paper investigates crane-related fatalities in order to find the upstream causation of such accidents. The National Coroners' Information System (NCIS) database was searched to identify fatal accidents in the construction industry involving the use of a crane. The narrative description of the cases provided in the coroners' findings and associated documents were content analysed to identify the contributing causal factors within the context of each case. The findings show that the most frequent crane-related accident types were those that were struck by load, and electrocution. The most prevalent immediate circumstance causes were layout of the site and restricted space. The two most commonly identified shaping factors were physical site constraints and design of construction process. Inadequate risk management system was identified as the main originating influence on the accidents. This paper demonstrates that a systemic causation model can provide considerable insight into how originating influences, shaping factors, and immediate circumstances combine to produce accidents. This information is extremely useful in informing the development of prevention strategies, particularly in the case of commonly occurring accident types.
\end{abstract}

Keywords: Cranes, accident causation, immediate circumstances, shaping factors, originating influences

Paper Type: Research article

\section{Introduction}

On the morning of 18 February 2013, a crane driver was fatally injured in an accident on a construction site in Melbourne, Australia (ABC, 2013). The deceased, 59, who fell 35 metres to his death, was a highly experienced crane driver. Over a ten year period (2004 to 2013), 359 workers died in the Australian construction industry due to work related causes (Safe Work Australia, 2013). During this period, the Construction industry accounted for $14 \%$ of all worker fatalities. The number of serious claims tells a similar story. During a five year period between 2006 and 2011, there were on average 13,105 serious cases recorded by Safe Work Australia (2013).

Cranes are involved in a significant proportion of construction accidents in comparison to other mobile plants. This problem is not unique to Australia. Crane-related fatalities represent more than $8 \%$ of all construction fatalities investigated by Occupational Safety and Health Administration in the US (Beavers, et al. 2006). Previous analyses of construction accidents, including those involving cranes, have typically focused on identifying immediate circumstances surrounding the accident. However understanding the systemic factors that produce the

Copyright: Construction Economics and Building 2015. (C) 2015 Ehsan Gharaie, Helen Lingard and Tracy Cooke. This is an Open Access article distributed under the terms of the Creative Commons Attribution 4.0 Unported (CC BY 4.0) License (https://creativecommons.org/licenses/by/4.0/), allowing third parties to copy and redistribute the material in any medium or format and to remix, transform, and build upon the material for any purpose, even commercially, provided the original work is properly cited and states its license.

Citation: Gharaie, E., Lingard, H. and Cooke, T., 2015. Causes of fatal accidents involving cranes in the Australian construction industry, Construction Economics and Building, 15(2), 1-12. DOI: http://dx.doi.org/10.5130/AJCEB.v15i2.4244

Corresponding author: Ehsan Gharaie; Email - ehsan.gharaie@,rmit.edu.au

Publisher: University of Technology Sydney (UTS) ePress 
immediate causes is potentially more useful (Beavers, et al. 2006). Shapira and Lyachin (2009) noted that accident reports typically identify the immediate physical factors involved in crane accidents but rarely trace an event back to its "root" causes. The research reported in this paper thus aimed to go beyond accident description and investigate crane-related fatalities in order to determine upstream causation of such accidents. The paper presents an exploratory analysis of construction accidents involving cranes in Australia. The analysis is based on extracted rich accident data from closed cases included in the NCIS, with the aim of tracing the causes and informing the development of preventive measures.

\section{Literature Review}

\section{Immediate Causes}

Previous research on the causation of crane accidents has looked into the immediate causes of the accidents and more specifically on the impact of the areas around the crane, and the type of the crane involved in the accident. One-hundred and twenty seven crane related fatalities that occurred in the USA between 1997 and 2003 were analysed by Beavers et al. (2006). The analysis reported the most frequent accident types to be: struck by a load (32\%); electrocution $(27 \%)$; crushed during assembly/disassembly (12\%); and the failure of the boom/cable $(12 \%)$. In another study, McCann (2009) analysed 323 fatalities in 307 crane incidents that occurred in the USA between 1992 and 2006. The results showed that a total of 102 fatalities $(32 \%)$ were electrocutions due to contact with overhead power lines. A total of 68 fatalities $(21 \%)$ were associated with the collapse of a crane and 59 fatalities $(18 \%)$ resulted from a worker being struck by a crane boom/jib.

These studies confirmed an earlier work by Shepherd, Kahler and Cross (2000) that developed a detailed taxonomy based upon Haddon's "damaging energies" theory to analyse the aetiology of crane accidents. Shepherd, Kahler and Cross argued that gravitational and electrical energyrelated accidents were over-represented in fatal accidents involving cranes.

Paques (1993) noted that unintentional contact with power lines is one of the most serious types of accident involving cranes. In a study incorporating data from Canada, the United States and France, Paques reported that the majority of accidents in which a crane unintentionally came into contact with a power line, involved electrical contact with the boom $(75 \%)$. However a further $17 \%$ of cases involved electrical contact with a cable, and 5\% involved electrical contact with the load, often a steel or timber frame. Paques reported that $90 \%$ of workers involved in events in which a crane made contact with a power line were ground helpers. Crane operators were only affected by unintentional contact with a power line when they left the cabin of the crane during the contact period. Beavers, et al. (2006) reported that most workers who died from cranerelated events were not crane operators but labourers or other specialty tradesmen working in the vicinity of the operating crane.

\section{Dangerous Areas around Cranes}

In order to identify the areas dangerous for workers in the vicinity of cranes, Luo, Leite and O'Brien (2011) conducted interviews with members of the Construction Industry Institute Community of Practice (CIICP). They reported such areas as: (i) the area under the crane load; (ii) the area around material stacks from which a crane is lifting/unloading materials; and (iii) the wing area of mobile cranes' superstructures. The following areas were identified as being dangerous areas in relation to the movement of the crane's load: (i) proximity to nearby structures; (ii) proximity to nearby roads, railways or waterways; (iii) proximity to overhead power lines; and (iv) proximity to other cranes' components. 


\section{Types of Cranes}

Research indicates that different types of cranes are associated with different levels of safety risk, and different types of accident (Nietzel, Seixas and Ren, 2001). For example Beavers, et al. (2006) reported that mobile cranes represented over $88 \%$ of the fatal events in their sample, of which 56\% involved a crane with a "lattice boom." Suruda, Egger and Liu (1997) reported the involvement of lattice-boom cranes in $93 \%$ of fatalities that were associated with assembly or dismantling (see also Shepherd, Kahler and Cross, 2000). In most cases the death occurred when a boom section, supported only by a hoist line, fell and struck a worker below. In comparison, only $7 \%$ of assembly/dismantling fatalities involved tower cranes.

The presence of power lines was determined to have only a moderate impact on safety in the vicinity of a tower crane (Shapira, Rosenfeld and Mizrahi, 2008). In contrast Beavers, et al. (2006) reported that accidents involving electrocution due to contact with power lines, in their sample, exclusively involved mobile cranes. By their very nature, mobile cranes are more susceptible to becoming unstable and, in the analysis by Beavers, et al. (2006), "crane tip over" events were only associated with mobile cranes.

Bernold, Lorenc and Luces (1997) identified specific risks associated with the use of truckmounted cranes when dragging a load, or in the abrupt extrication of a stuck object. This practice is relatively commonplace in civil engineering works, and resulted in a number of serious accidents.

Shapira and Lyachin (2009) identified factors affecting the safe use of tower cranes in the construction industry and then used an expert panel to judge the importance of each factor. The majority of factors rated by the experts as being "highly affecting" were related to human factors or safety management. "Operator proficiency" was rated the most important factor. However, among the project conditions "blind lifting" was rated as "high" in its ability to influence the safe operation of a tower crane. Shapira, Rosenfeld and Mizrahi (2008) reported that visibility limitations necessitating "blind lifts" occur in nearly all construction sites, and can be caused by extreme vertical distance between the operator and the loading/unloading areas, poor light conditions, physical obstructions and inconvenient angles of vision.

Tam and Fung (2011) undertook survey research to examine the causes of fatal tower crane accidents in the Hong Kong construction industry. They revealed a number of systemic contributing factors, including: (i) operators' fatigue induced by long work hours and insufficient rest breaks; (ii) inadequate risk management processes; and (iii) a breakdown in communication and safety responsibility arising as a result of the multi-layered sub-contracting system.

A methodology has been developed by Shapira, Simcha and Goldenberg (2012) for assessing the overall safety index for tower crane use in construction projects. This system involves measuring the extent to which a set of pre-determined contributing factors to tower crane accidents is present in a particular project. This information is then combined with weighted risk scales derived from experts' assessment of the potential for each factor to influence safety. Further variables are then applied as 'multipliers.' Thus the computational mechanism embedded in the system reflects: (i) the extent to which the tower crane operates outside the boundary of the site and the nature of the surrounding environment (i.e., whether it is not urban, a regular urban environment or a busy urban environment); (ii) the number of workers exposed to crane operations; and (iii) the nature and extent of crane use (i.e., utilization rate and work intensiveness). This knowledge has been incorporated into a computer-based assessment tool (see Shapira, Simcha and Goldenberg (2012) for details).

The research reported in this paper sought to analyse rich data contained in coroners' findings to explore the systemic causes of crane-related fatalities in the Australian construction industry. It goes beyond the immediate causes and investigates the root causes of such accidents. 


\section{Research Method}

The research adopted a multiple-case study research method. Qualitative approaches are well suited to qualitative research (Creswell, 2009) and the multiple case study design is useful in understanding "how" and "why" past events, in this case fatal accidents involving cranes, occurred (see Gerring, 2007; Yin, 2009).

First, the National Coroners' Information System database was searched to identify fatal accidents that occurred in the construction industry and which involved the use of a crane. The NCIS is a national database that captures data relating to deaths investigated by an Australian coroner. The database is managed by the Victorian Institute of Forensic Medicine and was developed to assist coroners to better identify and address recurrent hazards within the community. The data recorded in this database consisted of cases that involved investigation by a coroner. This database was maintained from the year 2000 to 2008. The researchers have examined the entire database for the purpose of this research and the results presented in the paper cover all the cases involving cranes in the associated construction projects.

To identify cases for analysis, two fields were used. The case status field was used to identify closed cases, as full investigation reports are only available for cases that are closed. Cases that were work-related were also identified using a field in which the investigating coroner records whether a death was work-related or not. To be included in the analysis, the following additional selection criteria were used:

- the decedent had to be a construction worker;

- the incident resulting in death had to have occurred on a construction worksite, thus travel incidents occurring as the decedent travelled to and from work were excluded; and

- the incident had to have involved a crane of some type.

A total of 258 closed cases were identified as resulting in the work-related death of a construction worker. Of these cases, 22 involved the use of a crane.

Second, the narrative description of the cases provided in the coroners' findings and associated documents were content analysed to identify what occurred and the contributing causal factors within the context of each case. The analysis of what happened was informed by a classification system developed by Beavers et al. (2006) who identified seven mutually exclusive types of crane-related fatalities as follows:

- Failure of boom/cable

- Crane tip over

- Electrocution

- Struck by load - other than failure of boom/cable

- Falls

- Crushed during assembly/disassembly, and

- Struck by cab/counterweight

The analysis of contributing causal factors was informed by an empirically derived model of accident causation developed by researchers at Loughborough University (Health and Safety Executive, 2003). This model has been used in subsequent analysis of construction accidents in Australia and the USA. It has been found to be useful in explaining the causes of both fatal accidents (Cooke and Lingard, 2011; Lingard, Cooke and Gharaie, 2013a; Lingard, Cooke and Gharaie, 2013b), and non-fatal accidents (Behm and Schneller, 2012).

The "Loughborough Model" posits that three levels of accident causes can be identified. These are immediate circumstances, shaping factors, and originating influences. According to this model, the immediate circumstances of accidents include the suitability, usability and conditions 
of tools, equipment and material, the behaviour, motivation and capabilities of workers, and features of the physical site environment such as layout, lighting and weather conditions. Shaping factors are the factors that precede the immediate circumstances, and include factors such as the level of supervision, site constraints, worksite design, poor communication within work team, the state of workers' health, and fatigue. According to the model, shaping factors are preceded by originating influences which can include the economic climate, the prevailing level of construction education, design of the permanent building/structure and the quality of project management, safety culture, and risk management in the construction project. Figure 1 demonstrates one example of the case analysis according the Loughborough model. A summary of this case is presented in the discussion section of this paper.

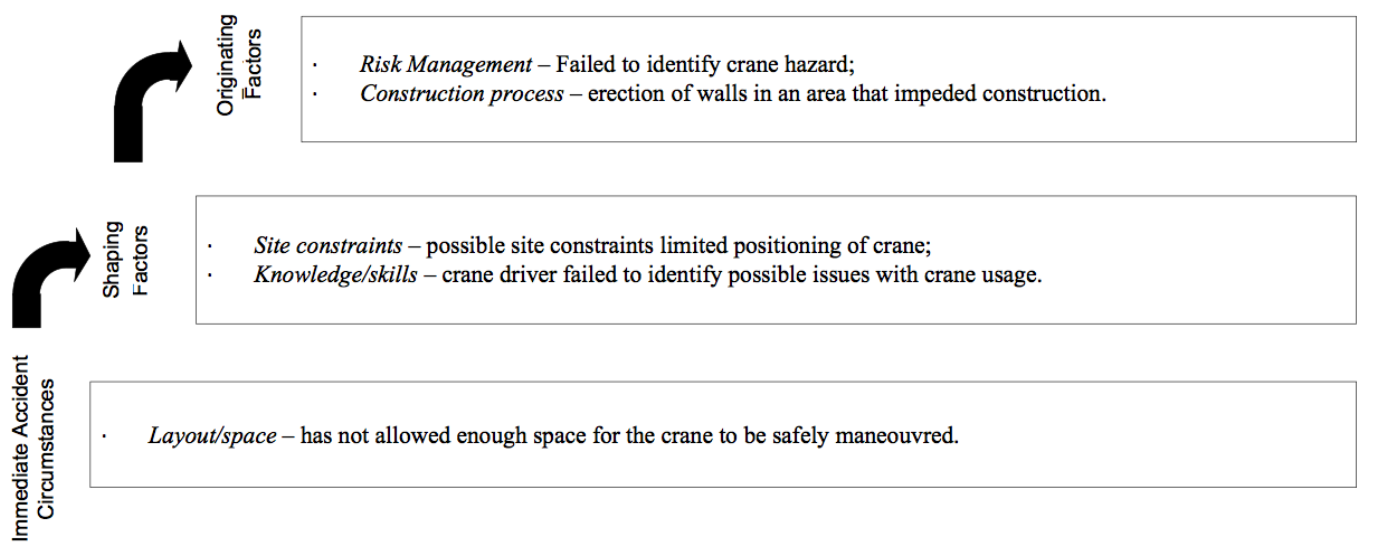

Figure 1: An example of analysis of crane accident causation using Loughborough model

\section{Results}

\section{Type of Incident}

Table 1 provides a brief description of each case and the classification of accident type. Figure 2 shows the frequency with which the different types of fatal accident involving cranes occurred in the 22 cases included in the analysis. In ten cases (45.5\%) the accident involved somebody being struck by a load. The second most frequent type of accident was electrocution (five cases, $22.7 \%$ ). Failure of a boom or cable occurred in three $(13.6 \%)$ of the 22 cases. Falls from a crane also occurred in three $(13.6 \%)$ of the cases. None of the Australian cases occurred during the assembly of the crane.

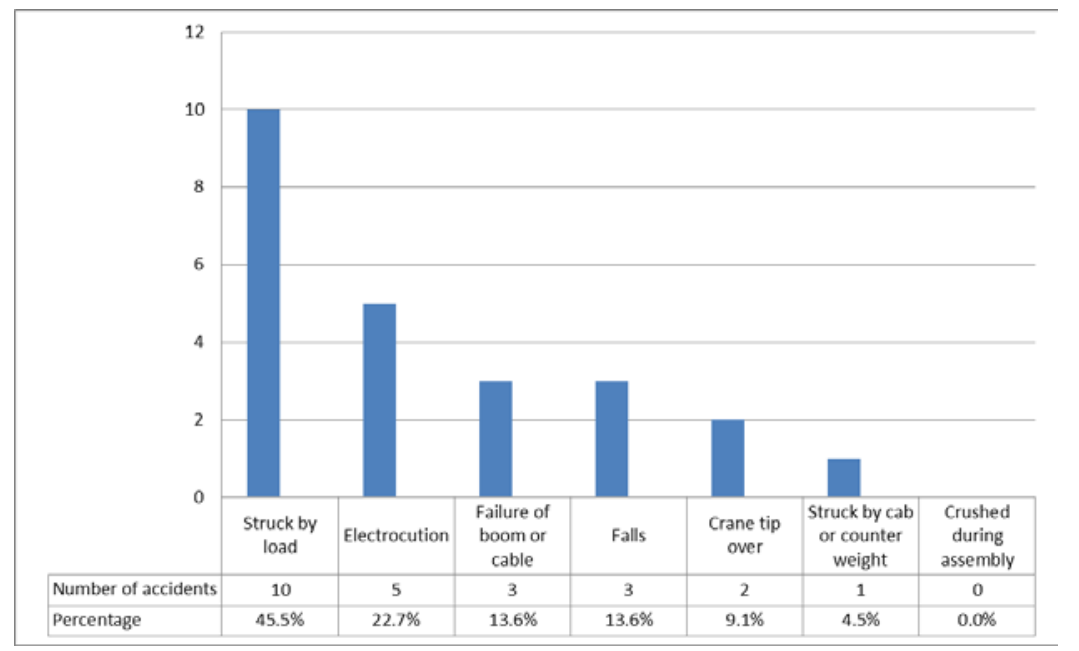

Figure 2: The frequency of different types of fatal crane related accidents 
Table 1 . Summary of cases and accident type classification

\begin{tabular}{|c|c|}
\hline Case summary & Type of incident \\
\hline The boom of the crane snapped at the pivot point. & Boom failure \\
\hline $\begin{array}{l}\text { The boom of the crane came into contact with overhead power lines. The decedent was } \\
\text { standing at the side of the truck and received an electrical shock. }\end{array}$ & Electrocution \\
\hline $\begin{array}{l}\text { A crane was delivering concrete in a concrete bin over the wall to the stairwell. As the boom } \\
\text { was raised the crane became unstable and began to tip. The decedent was struck by the falling } \\
\text { crane. }\end{array}$ & Crane tip over \\
\hline $\begin{array}{l}\text { The decedent was standing beneath the slab. At this point two slabs were on top of each } \\
\text { other. Both of the slabs then fell from their resting position and landed on top of the } \\
\text { decedent. }\end{array}$ & Struck by load \\
\hline $\begin{array}{l}\text { The decedent was operating a crane replacing sleepers on a railway line. The crane was being } \\
\text { used to remove sleepers from a flatbed rail car. This piece of machinery toppled from the rail } \\
\text { car and fell into a culvert beside the rail line. }\end{array}$ & Struck by load \\
\hline The decedent was struck by a steel beam that fell from a crane while it was being moved & Struck by load \\
\hline $\begin{array}{l}\text { A large crane was being used to erect tilt-up panels. The crane slewed around and the counter } \\
\text { weights attached to the rear of the control cabin knocked the concrete wall supports causing } \\
\text { the wall to fall. The concrete struck the decedent. }\end{array}$ & $\begin{array}{l}\text { Struck by cabin or } \\
\text { counterweight }\end{array}$ \\
\hline $\begin{array}{l}\text { The decedent was loading concrete pillars onto a truck when a pile of pillars collapsed onto } \\
\text { him from behind, crushing his body. }\end{array}$ & Struck by load \\
\hline $\begin{array}{l}\text { The structure was being supported by a crane operator who had the concrete beam attached } \\
\text { by chains to the crane. The decedent was operating a backhoe under structure when two } \\
\text { concrete beams fell after the canter lever gave way. The concrete beams landed on top of the } \\
\text { cabin of the backhoe. }\end{array}$ & $\begin{array}{l}\text { Struck by load, } \\
\text { Crane tip over }\end{array}$ \\
\hline $\begin{array}{l}\text { The decedent was guiding the lifting of trusses when he took a step back into a void for a } \\
\text { future stairwell. The decedent fell } 3.5 \mathrm{~m} \text { and hit his head. }\end{array}$ & Falls \\
\hline $\begin{array}{l}\text { The decedent was performing crane driving duties at a construction site while carrying out the } \\
\text { removal of a building. The decedent was apparently attempting to remove part of a concrete } \\
\text { wall when the wall fell and struck him. }\end{array}$ & Struck by load \\
\hline $\begin{array}{l}\text { A crane was used to lift the telegraph poles off the back of the truck, to place on the ground. } \\
\text { While being lifted, a telegraph pole became unbalanced. The top end of the pole came loose } \\
\text { and struck the decedent. }\end{array}$ & Struck by load \\
\hline $\begin{array}{l}\text { The boom of a crane failed at the hydraulic ram between stage one and two. This resulted in } \\
\text { stage three of the boom falling with force directly onto the decedent, pinning him to concrete } \\
\text { reinforcing. }\end{array}$ & Boom Failure \\
\hline $\begin{array}{l}\text { The concrete pylon fell and crushed the cabin of the crane. A witness then observed the boom } \\
\text { with the pylon driver attached also fall to the ground. }\end{array}$ & Boom Failure \\
\hline $\begin{array}{l}\text { The decedent was engaged in the positioning of concrete using a boom. The boom came in } \\
\text { contact with the overhead power lines giving the decedent an electric shock and throwing him } \\
\text { to the ground }\end{array}$ & $\begin{array}{l}\text { Electrocution, } \\
\text { Falls }\end{array}$ \\
\hline $\begin{array}{l}\text { The decedent was working at a construction site when a large concrete slab came loose from } \\
\text { the crane and fell onto him. }\end{array}$ & Struck by load \\
\hline $\begin{array}{l}\text { The decedents were crane operators, attempting to mount a light pole in the ground when it } \\
\text { came into contact with overhead power lines, resulting in both being electrocuted. }\end{array}$ & Electrocution \\
\hline $\begin{array}{l}\text { The decedent was moving a large shed from its foundations onto a large truck trailer when the } \\
\text { boom of the crane that the decedent was operating came into contact with high voltage } \\
\text { overhead wires. }\end{array}$ & Electrocution \\
\hline $\begin{array}{l}\text { The decedent was working on a construction site. He was on top of the overpass } \\
\text { approximately } 25 \text { feet above the ground. He fell due to an incident involving "bridge beams". }\end{array}$ & Falls \\
\hline $\begin{array}{l}\text { Equipment was being loaded onto the back of truck both by hand and by means of a crane } \\
\text { located on the back of the truck. During loading the crane contacted the single overhead } \\
\text { power-line. }\end{array}$ & Electrocution \\
\hline $\begin{array}{l}\text { The decedent was tasked to turn a large steel beam while it was suspended. During the } \\
\text { operation the beam slipped in the chain and struck the decedent. }\end{array}$ & Struck by load \\
\hline $\begin{array}{l}\text { The decedent and a co-worker were directing a crane driver on the placement of the mast } \\
\text { sections on the ground. While attempting to land a pack of mast sections on the ground, the } \\
\text { metal packing straps failed causing fourteen sections to fall from a height of two metres. One } \\
\text { of the falling sections struck the decedent on the head. }\end{array}$ & Struck by load \\
\hline
\end{tabular}




\section{Immediate Circumstances}

Figure 3 shows the immediate circumstances identified from the qualitative analysis of the coronial findings. Unfortunately, due to limitations inherent in the data, immediate circumstances of the accident could only be identified in 18 of the 22 cases. The most prevalent immediate circumstance identified in the 18 cases was layout of the site and restricted space in the vicinity of the crane ( $\mathrm{n}=14$ cases, $77.8 \%$ ). Unsafe actions taken by workers, including the crane operator and workers in the vicinity of the crane were identified as relevant circumstances in seven cases $(38.9 \%)$. The crane itself was also identified as an immediate factor contributing to the accident in another seven $(38.9 \%)$ cases. Other immediate circumstances identified in the analysis were local hazards in the vicinity of the crane $(n=2,11.1 \%)$, lack of personal protective equipment $(\mathrm{PPE})(\mathrm{n}=1,5.6 \%)$ and the prevailing weather conditions $(\mathrm{n}=1,5.6 \%)$.

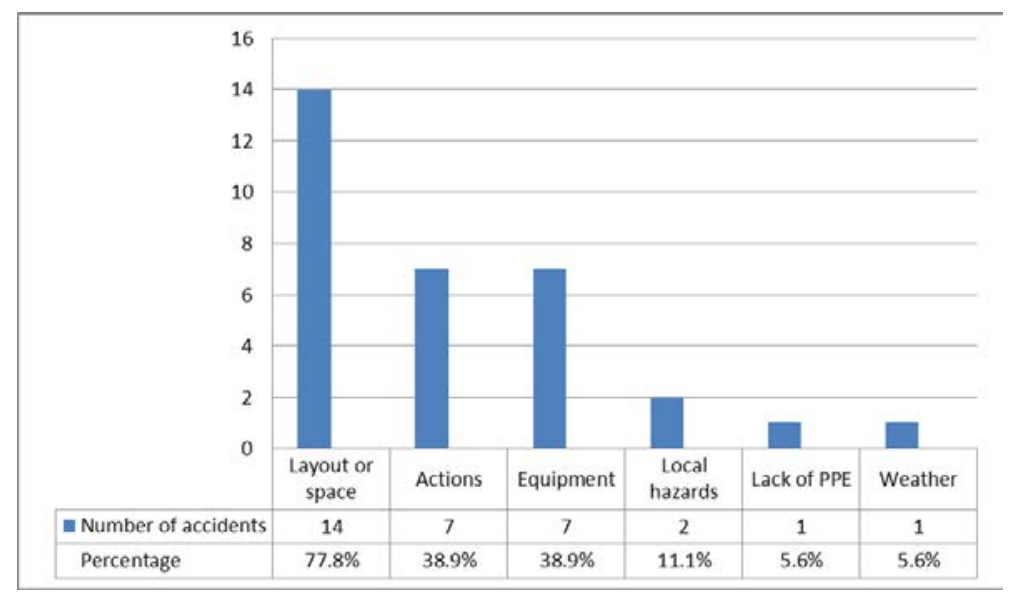

Figure 3: Number of accidents according to the immediate circumstances

\section{Shaping Factors}

Figure 4 shows the shaping factors identified from the qualitative analysis of the coronial findings. Due to limitations in the data, shaping factors of the accident could only be identified in 16 of the 22 cases. The two most commonly identified shaping factors were physical site constraints ( $n=9$ cases, $56.24 \%$ ) and design of the process of construction work $(n=8,50.0 \%)$. The level of skill and knowledge of workers was identified as being a relevant shaping factor in 5 of the cases $(31.3 \%)$. Other shaping factors that could be identified as being relevant from the case information provided in the coroners' reports were inadequate supervision of work $(\mathrm{n}=4$, $25.0 \%$ ), workers' attitudes and/or motivation $(\mathrm{n}=2,12.5 \%)$ and the scheduling of construction work $(n=1,6.3 \%)$.

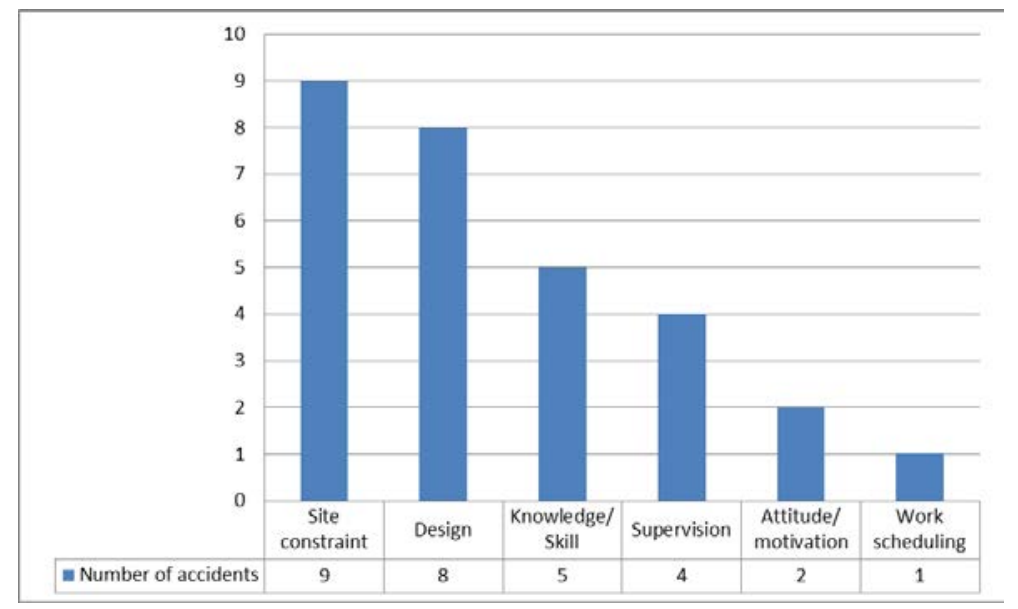

Figure 4: Number of accidents according to the shaping factors 


\section{Originating Influences}

Figure 5 shows the originating influences identified from the qualitative analysis of the coronial findings. Originating influences of the accident could only be identified in 13 of the 22 cases. The quality of risk management systems relating to the operation of the crane was identified as a relevant factor in nine of the fatal accidents for which originating influences could be identified, accounting for 69.2 per cent of these cases. The choice of method of construction was also identified as being a relevant factor in 8 cases $(61.5 \%)$. Aspects of the prevailing safety culture and the design of permanent structure under construction were each identified as being a relevant factor in 5 cases $(38.5 \%$ each). Failings in the management of the project could be identified as being relevant in 2 cases $(15.4 \%)$.

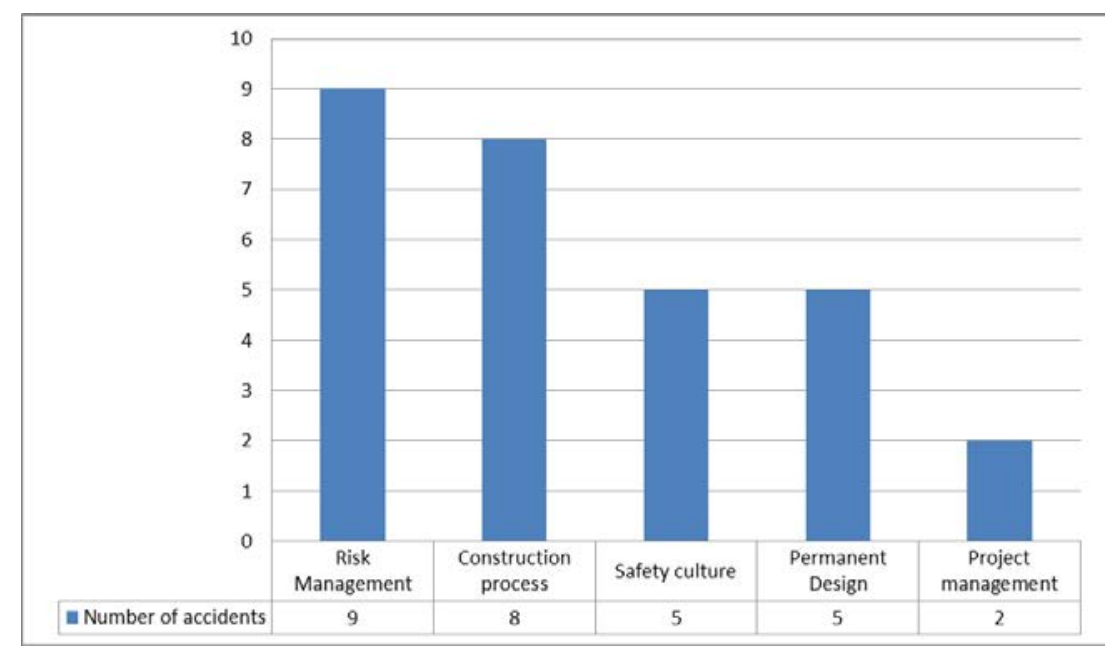

Figure 5: Number of accidents according to the originating influences

\section{Accident Pathways}

Each case was traced back to identify pathways linking immediate circumstances, shaping factors and originating influences in the 22 crane accidents in the sample. This analysis resulted in the production of a network diagram showing the relationship between contributing or causal factors at each level of the Loughborough accident causation model. The results are depicted in Figure 6.

The most commonly occurring accident types, identified in the NCIS database, were "struck by load" and "electrocution" events. The analysis revealed that these accident types involved different immediate circumstances. Electrocution accidents involved issues of site layout/space, local hazards, weather and workers' actions. "Struck by load" accidents involved issues of site layout/space, equipment and workers' actions. Site layout/space was a common cause of both of these types of crane accident, being a relevant factor in $50 \%$ per cent of accidents in which a worker was struck by a load and $100 \%$ of accidents resulting in electrocution. Five cases of struck by load and 5 cases of electrocution were related to this immediate circumstance.

The immediate circumstance of site layout/space was most commonly preceded by physical site constraints ( $\mathrm{n}=7$ cases) and design of the construction work process ( $\mathrm{n}=5$ cases). In turn, physical site constraints were most commonly related to the quality of risk management implemented at the project in ( $\mathrm{n}=7$ cases) and choice of construction method ( $\mathrm{n}=5$ cases). Construction work process design was most commonly preceded by issues relating to the design of the permanent structure ( $\mathrm{n}=4$ cases) and the choice of construction method ( $\mathrm{n}=5$ cases). 


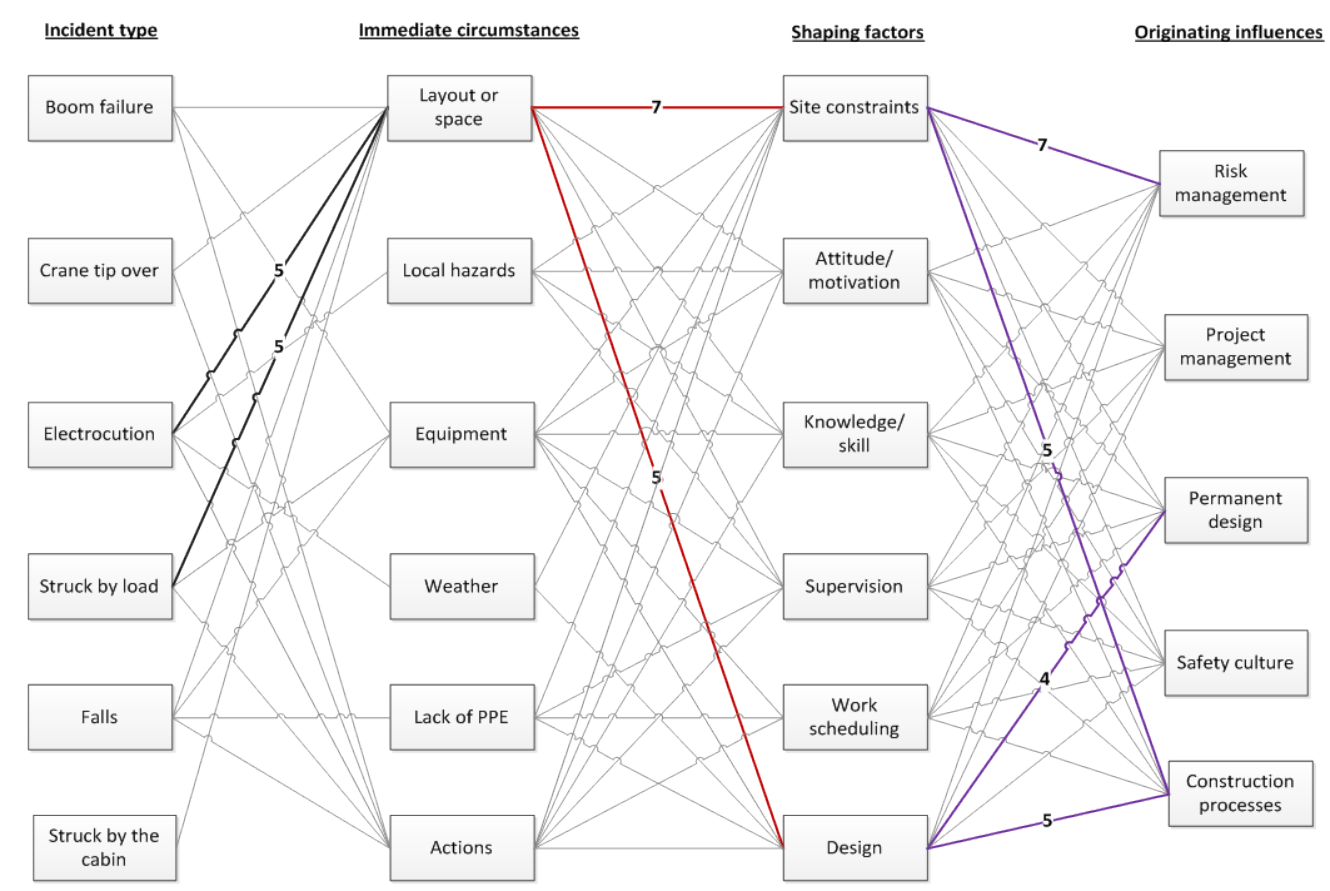

Figure 6: Accident pathways network

\section{Discussion}

\section{Accident Types and Causes}

Previous studies on accidents involving cranes focused on the accident types and immediate circumstances. This research has also looked into the types of the accidents. The results were consistent with research by Beavers et al. (2006) who concluded that the most common type of fatal accident involving cranes in the US construction industry were events in which people were struck by load or which resulted in electrocution. It was also apparent that the taxonomy developed by Shepherd, Kahler and Cross (2000) to classify crane accidents was applicable in the Australian construction industry. Hence these two common accident types are manifestations of damaging gravitational and electrical energies.

\section{Accident Pathways and the Relevance of "Upstream" Originating Influences}

The paper proposed accident pathways network for the analysis of root causes of accidents. The pathways could trace back the most frequent types of accident to the immediate circumstances, shaping factors, and originating influences. This information can be used by industry practitioners to focus their attention on the major upstream causes of the accidents, and maximise impact on safety improvements.

The analysis indicated that, "upstream" decisions made before construction work commences can contribute to the subsequent occurrence of very serious accidents involving cranes. In particular, the research revealed that design of the permanent structure, selection of construction method and quality of risk management were strongly related to the design of the construction process and site constraints which were, in turn, related to spatial and site layout issues, electrocution and "struck by load" accidents. These causal relationships are depicted in Figure 7.

The finding that some crane accidents can be traced back to decisions that are made prior to the commencement of construction work is consistent with the theory developed by Szymberski 
(1997) positing that the opportunity to influence safety is greatest during the early stages of a construction project and that this opportunity diminishes as the project progresses. The understanding that decisions made during the planning and design stages of construction projects can influence work health and safety during construction, has led to the development of legislative interventions in some countries, including Australia and the United Kingdom, to establish specific work health and safety responsibilities for "upstream" parties, including construction clients and design professionals.

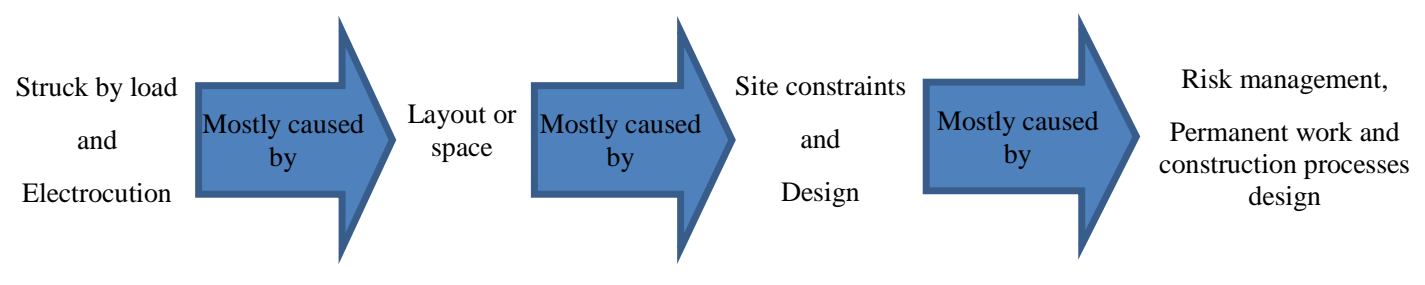

Figure 7: Causal roots of the stuck by load and electrocution accidents

\section{The Complexity of Accident Causality}

In the vast majority of accident cases, no single causal factor can be clearly identified and originating influence, shaping factors and immediate circumstances interact in complex ways. We use one of the incidents reported in this research to explain this point. This example reveals the complexity of accident causality in the construction industry.

In this case the decedent was undertaking the construction of showroom extensions. The project used a tilt-up panel method of construction. A tilt-up panel had been put in place and secured by a system of support struts at an earlier time. Work was being undertaken at the front of the site with the use of a large crane. As the crane slewed, the counter weights attached to the rear of the control cabin knocked the concrete wall, causing the wall to fall. The decedent saw the wall falling and attempted to run from the area but was struck and killed. The design of the permanent structure, choice of construction method, and risk management system were identified as relevant originating influences in the accident occurrence. Design of the process of construction and spatial constraints in the site environment were identified as relevant shaping factors. Finally, site layout and proximity of the slewing crane to the wall panel supports were identified as immediate circumstances of the accident.

When considering this example, it is important to note that the permanent design of the showroom extension and the selection of a tilt-up method of construction did not, in themselves, cause this accident. Rather, these decisions were relevant factors in the sequence of events leading up to the accident, which contributed in some way to the build-up of risk. Had the project risk management system been adequate, then it is probable that the safety issues associated with the construction work process would have been identified, assessed and managed. However, in the absence of a robust risk management system, an unsafe construction process was designed, which contributed to the operation of a crane in dangerous proximity to the wall panel supports.

\section{Applications of the Loughborough Model}

The research demonstrated that the Loughborough model can be very useful in analysing the causes of construction accidents to gain a better understanding about how and why accidents occur in the construction industry. In particular, the model can provide considerable insight into how originating influences, shaping factors and immediate circumstances combine to produce accidents. This information is extremely useful in informing the development of prevention strategies, particularly in the case of commonly occurring accident types. 


\section{Conclusions}

Cranes are involved in a significant proportion of construction accidents. The research investigated crane-related fatalities in order to find the upstream causation of such accidents. The National Coroners' Information System database was searched to identify fatal accidents that occurred in the construction industry which involved the use of a crane. The narrative description of the cases provided in the coroners' findings and associated documents were content analysed to identify what occurred and what the contributing causal factors within the context of each case were. The accident type classification developed by Beavers et al. (2006) and the "Loughborough" causation model were used to inform the analysis of accident causes.

Struck by load and electrocution were the most frequent types of accident. The most prevalent immediate causal circumstance was layout of the site and restricted space in the vicinity of the crane. The two most commonly identified shaping factors were physical site constraints and design of the process of construction work. These shaping factors were influenced by quality of risk management systems in nine of the fatal accidents for which originating influences could be identified. The analysis indicated that, at least in some cases, "upstream" decisions made before construction work commences can contribute to the subsequent occurrence of very serious accidents involving cranes.

This research is not based on a large statistical sample and therefore, the authors do not seek to make generalisations in their findings. However, the research produces a clearer understanding of the circumstances in which fatal accidents involving cranes occur. The conclusions concern the fact that fatal accidents involving cranes can be explained by causal factors at various levels (immediate, shaping and originating). This suggests that the safe use of cranes in construction requires a full understanding of the socio-technical context of a construction project - not just the immediate circumstances (i.e. the task, equipment and personnel).

The paper proposed the accident pathways network for analysis of the impact of upstream decisions. These pathways can be used for tracing the most frequent accident types to their immediate circumstances, shaping factors, and originating influences. Such pathways would indicate the potentials for effective strategies aiming for highest impact on the safety of the site.

The paper has also highlighted the importance of systemic analysis of accidents. Complexity of accident causation has been demonstrated. It has been argued that the accidents cannot be attributed to a single cause, but happen in a complex environment and therefore should be looked at systematically. The complexity of the accident causation shows that the causation models cannot be used in court cases against any entities however this information is extremely useful in informing the development of prevention strategies, particularly in the case of commonly occurring accident types.

\section{References}

Australian broadcasting Corporation (ABC) 2013, Melbourne crane operator killed in fall, [online] Available at: http://www.abc.net.au/news/2013-02-18/melbourne-construction-worker-killed-in-fall/4524486.

Beavers, J.E., Moore, J.R., Rinehart, R. and Schriver, W.R., 2006. Crane-Related Fatalities in the Construction Industry. Journal of Construction Engineering and Management, 132(9), pp.901-10. doi: http://dx.doi.org/10.1061/(ASCE)0733-9364(2006)132:9(901)

Behm, M. and Schneller, A., 2012. Application of the Loughborough construction accident causation model: a framework for organizational learning. Construction Management and Economics, doi: http://dx.doi.org/10.1080/01446193.2012.690884

Bernold, L.E., Lorenc, S. J. and Luces, E., 1997. Intelligent technology for truck crane accident prevention. Journal of Construction Engineering and Management, 123(3), pp.276-84. doi: http://dx.doi.org/10.1061/(ASCE)07339364(1997)123:3(276) 
Cooke, T. and Lingard, H., 2011. A retrospective analysis of work-related deaths in the Australian construction industry. In: Egbu, C. and Lou, E.C.W. (eds.) Proceedings 27th Annual ARCOM Conference. 5-7 September 2011. Bristol, UK: Association of Researchers in Construction Management, pp.279-88.

Creswell, J.W., 2009. Research design: qualitative, quantitative and mixed methods approaches. California, USA: SAGE Publications Inc.

Gerring, J., 2007. Case study research: principles and practices. New York, USA: Cambridge University Press.

Health and Safety Executive, 2003. Causal factors in construction accidents. Research Report 156. London: HMSO and Loughborough University.

Lingard, H., Cooke, T. and Gharaie, E., 2013a. The how and why of plant-related fatalities in the Australian construction industry. Engineering Construction and Architectural Management. 20(4), pp.365-80. doi: http://dx.doi.org/10.1108/ECAM-09-2011-0085

Lingard, H., Cooke, T. and Gharaie, E., 2013b. A case study analysis of fatal incidents involving excavators in the Australian construction industry. Engineering Construction and Architectural Management. 20(5), pp.488-504. doi: http://dx.doi.org/10.1108/ECAM-08-2011-0073

Luo, X., Leite, F. and O’Brien, W.J., 2011. Requirements for Autonomous Crane Safety Monitoring. In: Yimin Zhu, and R. Raymond Issa, eds. 2011. Computing in Civil Engineering. Miami, Florida US: American Society of Civil Engineers, pp.331-338. doi: http://dx.doi.org/10.1061/41182(416)41

McCann, M., 2009. Crane-Related Deaths in Construction and Recommendations for Their Prevention. Silver Spring, MD: The Centre for Construction Research and Training.

Nietzel,R.L., Seixas, N.S. and Ren, K.K., 2001. A review of crane safety in the construction industry. Applied Occupational and Environmental Hygiene, 16(12), pp.1106-17. doi: http://dx.doi.org/10.1080/104732201753339613

Paques, J. J., 1993. Crane accidents by contact with powerlines. Safety Science. 16, pp.129-42. doi: http://dx.doi.org/10.1016/0925-7535(93)90010-B

Safe Work Australia, 2013. Worker's compensation data. [online] Available at: http://www.safeworkaustralia.gov.au/sites/swa/statistics/workers-compensation-data/pages/wc-data

Shapira, A., Simcha, M. and Goldenberg, M., 2012. Integrative Model for Quantitative Evaluation of Safety on Construction Sites with Tower Cranes. Journal of Construction Engineering and Management, 138(11), pp.1281-93. doi: http://dx.doi.org/10.1061/(ASCE)CO.1943-7862.0000537

Shapira, A., Rosenfeld, Y. and Mizrahi, I., 2008. Vision System for Tower Cranes. Journal of Construction Engineering and Management, 134(5), pp.320-32. doi: http://dx.doi.org/10.1061/(ASCE)0733-9364(2008)134:5(320)

Shapira, A. and Lyachin, B., 2009. Identification and Analysis of Factors Affecting Safety on Construction Sites with Tower Cranes. Journal of Construction Engineering and Management. 135(1), pp.24-33. doi: http://dx.doi.org/10.1061/(ASCE)0733-9364(2009)135:1(24)

Shepherd, G.W., Kahler, R. J. and Cross, J., 2000. Crane fatalities a taxonomic analysis. Safety Science, 36, pp.83-93. doi: http://dx.doi.org/10.1016/S0925-7535(00)00017-5

Suruda, A., Egger, M. and Liu, D., 1997. Crane-Related Deaths in the U.S. Construction Industry 1984-94. Report No. D297. Washington, DC: The Centre to Protect Workers' Rights.

Szymberski, R., 1997. Construction project safety planning. TAPPI Journal. 80(11), pp.69.

Tam, V.W.I. and Fung, I.W.H., 2011. Tower crane safety in the construction industry: A Hong Kong study. Safety Science, 49, pp.208-15. doi: http://dx.doi.org/10.1016/i.ssci.2010.08.001

Yin, R.K., 2009. Case study research: design and methods. Thousand Oaks, CA, USA: SAGE. 